14 Жаңабекова А. Мәтіндер корпусына фонетикалық белгіленімдер енгізуге арналган нұсқаулық сипаттамасы // Ә. Жүнісбектің 80 - жылдық мерейтойына арналван “Қазақ фонетикасы” атты дөңгелек үстел материалдары. - Алматы, 2018., 19 қазан. - 53 - 58 бб. - Материаль научной конференции

15 Исаев С. Қазіргі құазақ тіліндегі сөздердің грамматикальққ сипатыл. - Алматы: Рауан, 1998. - 303 б. - Книга 16 ЫІққақов А. Қазіргі қ̧азақ тілі. - Алматы, 1991. - 382 б. - Учебное пособие

17 Азарова И.В. Морфологическая разметка текстов на русском языке с использованием формальной грамматики AGFL. Кафедра математической лингвистики СПбГУ // $\underline{\text { http://www.dialog- }}$ 21.ru/Archive/2003/AzarovaAGFL. htm. -Интернет ресурс

18 Наииональный корпус русского языка // http://www.ruscorpora.ru/ - Интернет ресурс

19 Дарчук Н.П. Автоматизований морфологічний аналіз тексту // http://linguist.univ.kiev.ua/courses_morph.htm - Интернет ресурс

\title{
References:
}

1. Sirazitdinov Z.A., Buskunbaeva L.A., İşmuhametova A.Ş., İbragimova A.D. İnformasionnye sistemy i bazy dannyh başkirskogo iazyka. - Ufa: Knijnaia palata RB, 2013. - S 32. - Kniga

2. İsaev S. Qazaq tıl bilımını̃ mäselelerı. - Almaty: Arys, 2008. - 624 b. - Kniga

3. Plungän V. A. Obşaia morfologia: Vvedenie v problematiku. - M.: Editorial URSS, 2000. - Kniga

4. Zaliznäk A.A. Gramaticheski slovär ruskogo iazyka. Slovoizmenenie. - M., 1980. - 880 s. - Slovär

5. Şaiahmetov Q. Ekı funksialyq afikster: filol. ğyl. kand. diss. - Almaty, 1973. - Disertasia

6. Nasilov V.M. “Afiksy vklüchenia”//Sb. Voprosy iazyka i literatury stran vostoka. - M. 1958. - Sbornik

7. Ganiev F.A. "O sinteticheskih i analiticheskih padejah v tatarskom iazyke." // Sb.Voprosy türkologii. - Kazän, 1970. - Sbornik

8. Habichev M.A. İmenoe slovoobrazovanie i formoobrazovanie kumanskih iazykah. - M.:Nauka, 1989. - 217 s. Kniga

9. Baskakov N.A. İstoriko-tipologicheskaia morfologia türkskih iazykov. - M.:Nauka, 1979. - Kniga

10. Zaharov V.P., Bogdanova S.İu. Korpusnaia lingvistika. İrkutsk: İGLU, 2011. - S. 7. - Uchebnoe posobie

11. Baranov A.N. Kömpüternaia lingvistika // Vvedenie v prikladnuiu lingvistiku: Uchebnoe posobie. - M.: Editorial URSS, 2003. - S. 13-38. - Uchebnoe posobie 12

12. Jubanov A.K., Janabekova A.A. Korpusnaia lingvistika. - Almaty: Kazak tili, 2017. - S 5. - Uchebnoe posobie

13. Junisbek A. Problemy kazahskogo iazykoznania. - Almaty: Abzal-ai, 2018. - S. 80. - Kniga

14. Jañabekova A. Mätınder korpusyna fonetikalyq belgılenımder engızuge arnalğan nūsqaulyq sipattamasy // Ä. Jünısbektıñ 80 - jyldyq mereitoiyna arnalğan “Qazaq fonetikasy” atty döñgelek üstel materialdary. - Almaty, 2018. 19 qazan. - 53 - 58 bb. - Materialy nauchnoi konferensii

15. İsaev S. Qazırgı qazaq tılındegı sözderdıñ gramatikalyq sipaty. - Almaty: Rauan, 1998. - 303 b. - Kniga

16. Ysqaqov A. Qazırgı qazaq t1l1. - Almaty, 1991. - 382 b. - Uchebnoe posobie

17. Azarova İ.V. Morfologicheskaia razmetka tekstov na ruskom iazyke s ispölzovaniem formälnoi gramatiki AGFL. Kafedra matematicheskoi lingvistiki SPbGU // http://www.dialog-21.ru/Archive/2003/AzarovaAGFL. htm. İnternet resurs

18. Nasionälnyi korpus ruskogo iazyka // http://www.ruscorpora.ru/ - İnternet resurs

19. Darchuk N.P. Avtomatizovani morfologichni analız tekstu // http://linguist.univ.kiev.ua/courses_morph.htm Internet resurs

МРНТИ 17.17.01 https://doi.org/10.51889/2020-4.1728-7804.61

\author{
Raeva G., ${ }^{1}$ Ilyassova.$^{2}$ \\ ${ }^{1,2}$ Kazakh national pedagogical university named after Abai, \\ Almaty, Kazakhstan
}

\section{TURKIC WORD: VARIANTS AND MEANING}

\section{Abstract}

The article deals with variant words in the Turkic languages. From the historical point of view the significance of synharmonic variants and parallels is in the following: the phenomenon plays a special role in a methodological aspect in order to restore ancient roots and phonemes in their previous forms. We vividly observe the fact when we compare words 
pronounced via forelingual vowels with words pronounced via backlingual vowels. Comparing words pronounced through forelingual vowels with words pronounced through backlingual vowels we have made the following conclusions. In the result of language development during a long period of time backlingual and midlingual vowels and consonants moved to the front part of a tongue. Indisputably this is the influence of natural conditions, the change of physical qualities of a man (height fall, constitution decrease, etc.)

We have analysed hard variants of words having become softened in the Kazakh literary language or its dialects may present much more materials in this respect. Historical written memorials that reached our time prove the absence of soft pronounced sounds and the usage of their hard variants. Having researched and analysed carefully the words pronounced with soft vowels in Turkic (including Kazakh) languages we can restore almost all of them in their hard forms as in ancient Turkic because hard variants pronounced softly at present can be observed in one or other Turkic languages, their dialects, set expressions, onomastics, toponimics, historical writings, etc. This article analyzes controversial issues in the study of variant words in the Turkic languages

Keywords: turkic languages, synharmonism, historic compliance, variants, vowels, consonants

\author{
Раева Г.М., ${ }^{1}$ Ильясова Н.А. ${ }^{2}$ \\ ${ }^{1,2}$ Қазақ ұлттық педагогикалық университеті, \\ Алмать, Қазақстан
}

\title{
ТУРКІ СӨЗІ: ВАРИАНТЫ ЖӘНЕ МАҒЫНАСЫ
}

Мақалада түркі тілдеріндегі вариантты сөздер қарастырылады. Тіл тарихы тұрғысынан методологиялық аспектіде вариантты сөздерді талдау көне түбірлер мен формаларды қалпына келтіруде маңызды орын алады. Бір мағына беретін, түрлі нұсқада бірде тіл алды, бірде тіл арты дауыстыларымен айтылатын сөз вариантарын зерттеуде осы құбылыс байқалады. Тілдің дамуы барысында тіл алды, тіл ортасы дауыстылары, дауыссыздары тіл алдына қарай жылжыған. Табиғат жағдайларының, адамның физикалық белгілерінің өзгеруі де осы құбылыстың пайда болуына әсер еткен. Қазақ әдеби тілінде, диалектілерінде жуан дыбысталатын сөз варианттары бар. Сонымен қатар, туыстас түркі тілдері мен олардың жергілікті тіл ерекшеліктерінде де жуан түбірлерді кездестіруге болады. Көне жазба ескерткіштер тілінде ерте кезеңдерде де жарыспалы қолданылатын сөздердің жуан, тіл арты дауыстылары болған, жіңішке дауыстылар қолданылмаған. Мақалада осы мәселе жан-жақты талданады.

Түйін сөздер: түркі сөзі, тіл тарихы, тарихи өзгеріс, сөз варианты, дауысты, дауыссыз

\author{
Раева Г.М., ${ }^{1}$ ИльясоваН.А. ${ }^{2}$ \\ 1,2 Казахский педагогический университет имени Абая, \\ 2.Алматы, Казахстан
}

\section{ТЮРКСКОЕ СЛОВО: ВАРИАНТЫ И ЗНАЧЕНИЕ}

\section{Аннотация}

В статье рассматриваются вариантные слова в тюркских языках. С точки зрения истории языка значение вариантных слов и параллелей заключается в следующем: данное явление играет весьма особую роль в методологическом аспекте по делу восстановления в прежней форме древних корней и фонем. Мы это ясно наблюдаем, когда сравниваем между собой слова, произносимые через переднеязычные гласные, со словами, произносимыми через заднеязычные гласные. В результате развития языков на протяжении бесконечно долгого времени заднеязычные и среднеязычные как гласные, так и согласные передвинулись к передней части языка. На это, безусловно, повлияли природные условия, изменения физических данных человека. Твердые варианты смягченных слов мы искали в казахском литературном языке или в его диалектах (говорах). Родственные тюркские языки или их диалекты могут представить гораздо больше материалов в этом отношении. Дошедшие до наших времен исторические письменные памятники однозначно доказывают, что в эпоху древнетюркских времен абсолютно не было мягко произносимых слов, в употреблении были только их твердые варианты. Исследовав скрупулезно и подвергая тщательному анализу все слова, произносимые с мягкими гласными в тюркских (и в казахском в том числе) языках, можно восстановить их, почти все, в твердых формах, имевших место в древнетюркском языке, потому что древние твердые варианты ныне мягко произносимых слов обнаруживаются если не в одних, то в других тюркских языках или их диалектах, в устойчивых словосочетаниях, в ономастике и топонимике, в исторических памятниках и т.д. В данной статье анализируются спорные вопросы в изучении вариантных слов в тюркских языках

Ключевые слова: тюрксое слово, история языка, исторические соответствие, варианты, гласные, согласные 
Introduction.Tunguzo-manjurian, mongolian, turkic, (in a broad sense - languages of the ural-altaic family) languages had experienced polysynthetic or amorphous state before they became agglutinative. In its earliest form the language underwent destruction because of unknown reasons but later it was restored having saved generic semantics of a word, there appeared a law of synharmonism. Among Altaic languages the synharmonism is well-preserved in Turkic languages.

Phonetic, phonomorphologic structure of words is different in various languages. The only characteristic feature for Turkic languages - harmony of vowels.

According to the definition given by a well-known phonologist A. Zhunisbekov synharmonism as a fundamental structural typological phenomenon joins sounds into one whole unit. It differentiates words in the stream of speech, at the same time it serves as a word-formation element [7, 68-78]. In a case of synharmonism a special role is given to vowels as they together with a consonant form a syllable, define their common nature.

As a result of the latest achievements in linguistics synharmonism is considered to be not only as the harmony of vowels but also as a united phonetic complexity of a vowel and a consonant in the structure of a word.

In modern Turkic languages synharmonism is manifested in two kinds: backlingual vowels are in harmony with backlingual vowels, forelingual vowels are in harmony with forelingual vowels. This is called palatel harmony. But there are cases when labial vowels of the root syllable govern non-labial vowels in the following syllables making them similar to itself. This case is called labial harmony.

Materials and methods. In the process of research various methods are used: descriptive including the study of the factual material, generalization, interpretation, comparative historical analysis (research of Turkic languages, dialects and ancient turkic writings).

Such a composite approach allowed us to carry out a systematic study of synharmonic variants and parallels in the Kazakh language.

Results. In Turkic languages among them in a lexical structure of Kazakh there are fairly good number of words that do not observe the basic law of synharmonism even with the presence of a common adequate lexical meaning of a root. They are pronounced as different vowels: either forelingual, backlingual or open and narrow. Besides they form various kinds of equivalents. For example, а-ї darïlda дїрїлда (cry, shout), bajilda-bijilda (cry sharply, make noise); a-e kauak keueк (empty, vacant), badirai bedirei (distinguished abruptly), a- ä ajïm ajim (wrinkles); o-ö dongala döngele (round), tapbïi tapbïi (spred, open wide), balbïra bïlbïra (to grow languid), arsy ïrsy (to gape), baldïrla bïldïrla (to talk abstrusely, undistinctly, to mumble), zharbi zhïrbi (to sit bowing), dardai dïrdai (enormous, very strong), dabïs $\sim$ dïbïs (fame, glory), bazhrai bezhrei (being is wide open, to gape), batti bïtti (to look intently, to look insolently, with a call), mankïy mïnkïy (to look apathetically, to contemplate), tarsil tarsï (knock); a e: kauak kеuек (empty, hollow), azhïray ezhirey (to be surprised, to lose one's head, to stop ), alanda elende (distracted, to worry); a $\sim$ ä : akirranda $\sim$ äkirende (to threaten, to scold, to shout at); a o: adïray odïray (to goggle eyes), zhanka zhonka (silks, shaving), balbïra bolbïra (to become languid, to become inactive); a u: darïlda dïlrïlda (to thunder, knock, yell), dangïr dÿngir (knock, hum); o e kokay kekey (to stick out, exude between other, to be distinguishet, stand out), odïray $\sim$ edirey (to look goggling); u $\sim$ y: zhuta $\sim$ zhÿde (to lose

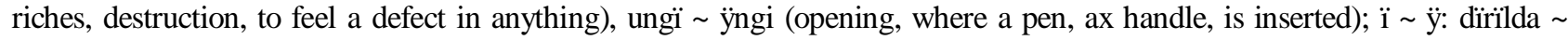
dÿrilde (to thunder, knock), bïksï bÿksi (to smoke, smoked, rot, smell).

Root vowels of monosemantic parallel words are alternated between themselves not only in a literary language but also in local dialects. For example, ojar-ojir (insolent, rude), kajar kajï (strength, persistence, energy), arkalï arkïlï (across, along), a ï: ayla ïyla (cunning, adroitness, exit, shrewdness, skill, possibility, shonzhar shonzhïr (brought back), shatil shïtil (to be complicit in improper businesses, tangled), dabïl dïbïl (appeal, signal, rumor, rumour, drum), kazhar $\sim$ kazhïr (force, persistence, energy), arkalï arkïlï (through, on, in), aikïra aikara (wide open, unbuttoned); a e: asili - äsili (essence, creature, basis, root), kaudïra keudire (to publish a rustle, rustle), alzhuas älzhuas (thin, tender, weak, sickly, emaciated), zhala zhäla (false prosecution, slander), ), zhapïray zhäpirey (to sit bowing), aran ären (hardly, barely), arman $\sim$ ärmen (farther, there), aura äure (fuss, troubles); a e: kaksa kekse (elderly), babaula bebeule (to yell, moan from pain), dangaradai $\sim$ dengeredei (large, excessive, empty and high building, building ); o u: koima $\sim$ kyima ( storage), domala $\sim$ dumala (to roll), shoynak $\sim$ shuynak (lame), soltan $\sim$ sultan (sultan), orpak $\sim$ urpak (posterity), ozhdan $\sim$ uzhdan (honour, conscience), oksas uksas (alike, similar); ö ÿ: kölÿk kÿlÿk (cart, draught animals, pack cattle, transport), shöbere $\sim$ shÿbere (great-grandchild, great-grandchild), könil keyil (desire, attention, mood), noser $\sim$ nuser (thundershower); o ö : solpi sölpi (ot to care a rush, indifferent, indifferent, typical), korekten $\sim$ körekten (to feed, accept food); u ̈̈: ulpa ÿlpe (loose, fluffy), ubïrlï-shubïrlï ÿbirli-shÿbirli (having many children family), uyma -zhyma ÿyme -zhÿme (unloaded, hammered together in a heap, in crowd), muzhï mÿzhi (to nibble, nibble a bone), duyïm duyim (numerous, on all size); $\mathrm{u}$ $\sim$ ï: bulak bïlak (source, key), tumau tïmau (rheum), tunuk tunïk (transparent, clean), shulgau shïlgau (footcloths), munda mïnda (hiere); ï i: shil shil (bearded partridge), tïyïmdï tiyimdi (useful, comfortable, adjusted, necessary), tïyïstï tiyisti (necessary, due, fixed), sïngan singen (sucked in, tried on, imbued), bïrtalai birtalai (considerable, handsome), mïsbakpau misbakpau (not move); u i: undeme indeme (keep silence, don't speak), shuberek $\sim$ shiberek (rag, shred), tubut $\sim$ tibut (uzz, goat's fuzz), tulik tilik (cut), tulki tilki (fox) и др [3, 12-46].

Equivalents of vowels formed by alteration free from the law of synharmonism are met in other Turkic languages by a comparative study of them. For example, in a Bashkirian language: a-ä asï äse (bitter, sour), as äs (quietly, slowly), akïrïn äkiren (few, little), in the Tatarish language: a-ä acï - äce (sour), akrïn äkren (quietly, slowly); in a comparative study of Turkic languages $\ddot{i} \sim 1 \sim$ e $\sim$ i yakut tïl $\sim$ tuv dill $\sim$ kirg., nog., kum., uzb til $\sim$ turkish, turkmen., azerb., gag. dil tatar, bashk., tel kaz til [ 5, 143-144]. 
Among words common for the Kazakh language and historical written memorials there are parallel phonetic variants meaning one and the same notion. For example, a-i a ï: tač "out of, appearance", tis - "appearance, exterior, external"; tamar - "blood vein" - tamï "blood vein", kanï ? (where) -kane? "which" (an interrogative pronoun); tadlïg - "tasty, sweet”, tätti "sweet, tasty"

Words "kop" (many), "karï " (old), "kyiaš" (sun) in modern Kazakh have the form köp, käri, kÿn. We see that the words pronounced historically as hard vowels nowadays are pronounced as soft. If we suppose that words "kop" , "karï" , "kyiaš" are relic of their turkic origin, we can guess that consonants $\mathrm{k}$ and its voiced variant $\mathrm{g}$ appeared later in the process of the historical evolution.

At the same time vowel equivalents $\mathrm{y} \sim \ddot{\mathrm{y}}, \mathrm{o} \sim \mathrm{o}$, a ä given in above-mentioned examples present the result of ancient and up-to-date times. Words "kyias" and "kÿn" were used as middle-age language memorials, but words "karï" and "käri” are used in modern Kazakh. The word "kyiaš" is supplanted by its soft variant "kÿn". A hard form of a word "äje" meaning "grandmother, mother, father's mother" has the form "aja". The latter is met in a proverb "Ai der aja jok" (There's no senior to say "hey!", no master to say "leave it"). In the poem "Khibatul Khakaik" there is a line "igit koja bolur". The old "koja" in ancient turkic meant "an old person, man". Taking into consideration the fact that our ancestors recognized elder people as heads of a community it comes out that any elderly person in a house is considered to be a master with full rights and full power. Possibly the word in the meaning "ruler of the country, lord" was used at that time in reference to the head of a religious commune arriving from arabian countries.

In a proverb "Ai der aja jok, koi der koja jok" a word "koja" functions in the meaning "ata" (grandfather), a word "aja" in the meaning "äje" (grandmother). "Aja" has the same root of the word "ajïm" (wrinkles on the face). "Ajïm" remained in local dialects of a conversational speech, in a bookish language as "äjim". Probably the word "aja" derived from grandmother's wrinkled face. Words "aja" and "äje" are considered to be variants of one and the same word.

In Kazakh the meaning of the word "lake" is conveyed as "köl". Logical development of turkic languages gives the opportunity to restore the word as "kol", but the word "kol" has a different meaning from "köl", having the sense "hand". That is why we are to analyse other words having indirect relation to a river or a lake in a somatic plane. "In the Azerbaijanian language gol-estuary, river merging", - writes one of the famous linguistics G. Musabayev. In the ancient Bashkirian language "kol" was used in the meaning "river estuary". In the Mongolian language the river is called gol. It is obvious that the names Karakol, Narïnkol, Bainkol the second components kol present the meaning "river", "river bed" [4, 24-25]. It is possible that the words lake, river in their original form sounded as "kol". In time the word differentiated its semantic meaning. G. Musabayev connects the meaning of the word with "kol" as "hand" (part of a man's body). According to the rules of semantics a large river was deemed to be akin to a man's body, small rivers falling into the main river seemed similar to a man's hands joined with the body.

Proof: in the Azerbaijanian, Bashkirian languages "gol", in Kazakh "koltik" is used in the meaning "one of river estuaries". Such an expression of a linguist has its sense: in the ancient Turkic language kökus - "chest", ögus - "river" [ 1].

If to take into account the inconstancy of a consonant $\mathrm{k}$, it becomes vivid that these words are formed according to the rule of likening. If so, the words "köl" (river) and "kol" (hand) were indisputably variants of one and the same word. As follows from the above a hard variant of a word was used parallelly with its soft variant, and then with the period of time the latter variant was gradually forced out of the use.

The above-mentioned examples allow us to observe the fact that alternation of open, narrow, forelingual and backlingual vowels in the root of definite words free from the law of synharmonism is the historic phenomenon embracing all Turkic languages. But word variations are not always adequate. Among them we all encounter words having various semantic differences or words that had acquired some stylistic functional shades. For example:

apat-opat. Apat - "disaster, spontaneous disaster, accident"; opat - "die". The word "apart" expresses the notion about the future or present events, whereas the word "opat" expresses the notion about past, completed events.

Tat-tot. Tat - "rust"; tot "oxide", tan (tot basu - to be covered with rust)". One of the words show the process of the action, another - the result of the action.

Discussion. One of the well-known linguistics D. G. Kiekbayev considers vowel variants of words encountered in Turkic languages as rightful and calls them "synharmonic parallels". He reminds us that for the first time this term was mentioned in 1951 by a researcher of the Hungarian language I. Balash [ 5, 147]. M.L. Cherkasskiy suggests to call monosemantic words as "synharmonic variants": parallel roots slightly differing from each other in their meaning as "synharmonic parallels" [ 2, 69-70]. M. Mollova gives the following proof of the discrepancy of the term between its content and meaning: "Spontaneous transition i.e. the equivalence of one of phoneme to the other is a phonetic phenomenon. Alternation of vowels in words without any phonological meaningful load is historic phenomenon. Owing to this the given term is unsuccessful, it cannot embrace the meaning of words in full [6,59]. On the one hand M. Mollova's point of view is appropriate. It's irrelevant to use the term "synharmonic" when we speak about words free from the law of synharmonism and variants formed on the basis of alteration of vowels in definite roots. But we use the term as it was accepted in linguistic works.

There were many suppositions in connection with the origin of synharmonic variants and parallels, about their genetic roots and so on. But linguistics-turkologists did not come to certain generally recognized conclusions.

The difficulty in solving this matter is in: sometimes historic alteration of sounds are at hand but the reasons of alteration are unknown. We state changes of sounds in speech but we cannot explain the change not by the influence of neighbouring sounds, not by the influence of stress, not by analogy of sounds, etc. Such alteration of sounds is called spontaneous. 
Quite a lot of scientists worked hard in order to find out the reasons of alternation of vowel sounds. G.I. Ramstadt, M. Ryasyanen, N. A. Baskakov, E.V. Sevortyan, D.G. Kiekbayev, A. M. Chsherbak put forward the supposition that alternation of vowels in the first syllable possibly depends on the influence of combinatory, positional distribution of surrounding consonants or as they consider it depends on the influence of vowels placed in subsequent syllables (affixes). A. Gaben, N.A. Baskakov, E.V. Sevortyan, N.G. Egorov, A.I. Yapharov explain the matter from another viewpoint; they say that vowels underwent changes due to various spontaneous alterations that's why they turned into labial or unlabial, open or narrow, backlingual or forelingual vowels. N.A. Baskakov, E.V. Sevortyan, A.M. Chsherbak, G.I. Ubryatova express the idea that synharmonic variants in Turkic languages appeared possibly because of mixture of different dialects. M.L. Cherkasskiy gives the following opinion about synharmonic variants and parallels. Turkic languages had polysynthetic structure before they turned to be agglutinative in ancient altaic epoch. According to the polysynthetic structure separate words are joined into complexity which is submitted to the law of synharmonism.

Conclusion. Vowels are harmonised not only by their hard, soft, labial features but also by open, narrow features. On account of vowels having carried no phonological load their pronunciation depended on consonants. Because of this qualitative alteration of vowel sounds have arisen. Therefore synharmonic variants and parallels produce the relic remained in the process of evolutionary development of Turkic language structure [2, 54].

1 Ancient turkic dictionary. Leningrad, 1969, 657 p.

References:

2 Cherkasskiy M.A. Turkic vocalism and synharmonism. Historical typological research experiment. Moscow, 1965, $142 \mathrm{p}$.

3 Dialectological Dictionary. Almaty, 2007, 800 p.

4 Kenesbayev I., Musabayev G. Contemporary Kazakh Almaty, 2010, 300 p.

5 Kiekbayev D.G. About vowel alteration in the Bashkirian language. Research Notes of Baskirian State Pedagogical Institute, VIII, philog. series 2, Ufa, 1956, pp.221-229.

6 Mollova M.K. To the History of Turkic Vocalism. Issues of Linguistics, 1966 № 2, pp. 56-65

7 The structure of Kazakh language. Almaty, 1991, $123 \mathrm{p}$.

\section{References:}

1. Drevnetürkski slovär. Leningrad, [Ancient turkic dictionary]1969, $657 \mathrm{s.}$

2. Cherkasski M. A. Türkski vokalizm i singarmonizm. İstoriko-tipologicheski issledovatelski eksperiment. [Turkic vocalism and synharmonism. Historical typological research experiment]Moskva, 1965, $142 \mathrm{~s}$.

3. Dialektologicheski slovär.[ Dialectological Dictionary] Almaty, 2007, 800 s.

4. Kenesbaev İ., Musabaev G. Sovremennyi kazahski Almaty, [Contemporary Kazakh Almaty]2010, $300 \mathrm{s.}$

5. Kiekbaev D. G. Ob izmenenii glasnyh v başkirskom iazyke.[ About vowel alteration in the Bashkirian language.] Nauchnye zapiski Baskirskogo gosudarstvennogo pedagogicheskogo instituta, VIII, filog. seria 2, Ufa, 1956, s. 221-229.

6. Mollova M. K. K istorii türkskogo vokalizma.[ To the History of Turkic Vocalism. Issues of Linguistics] Voprosy iazykoznania, 1966 № 2, s. 56-65

7. Struktura kazahskogo iazyka. Almaty, [The structure of Kazakh language]1991, $123 \mathrm{~s}$.

МРНТИ 17.82.31 $\quad$ https://doi.org/10.51889/2020-4.1728-7804.62

Саметова Ж. Ш. ${ }^{1}$

${ }^{1}$ Абай атындавы Қазақ ұлттық педагогикалық университеті, Алматы, Қазақстан

\section{ҚАЗІРГІ ҚАЗАҚ ПРОЗАСЫНДАҒЫ НЕОРЕАЛИСТІК (МАГИЯЛЫК) КӨРКЕМДІК ІЗДЕНІСТЕРДЕГІ АҒЫМДАР}

Көркем сөз кестесімен өрілген әдеби шығармалардың бейнелілігі мен дәлдігін, ұлттық тілдің сұлу айшықтарын жан-жақты танытуда түрлі әдіс пен тәсілдерді қолдану тиімді болып отыр. Соңғы кездері әдебиеттану ғылымының әр саласы бойынша дәстүрлі зерттеулермен қатар әдебиетті жаңа әдіс-тәсілдер, технологиялар арқылы талдау да кең өріс алуда. Осыған орай осы мақала қазіргі қазақ прозасындағы көркемдік ізденістер мен ағымдардың жаңа мәселесіне арналады. Яғни, қазіргі әдеби процессті жаңаша бағытта зерттеуге көңіл бөлінбегендігі және бүгінгі әдебиеттің ағымдық жүйесінде көкейкесті мәселеге айналып отыр. Көркем әдебиет үнемі өзгеріс пен қозғалыстағы ұғым болғандықтан, оны зерттеп-зерделеудің әдістемелері де күн өткен сайын жаңарып отырмақ. Сондай-ақ осы 